\title{
A comparison of oxygen debt in small and large rainbow trout, Salmo gairdneri Richardson
}

\author{
E. M. GoOLISH \\ University of Michigan, School of Natural Resources, Ann Arbor, MI 48109, U.S.A. and \\ Ministry of Agriculture, Fisheries and Food, Fisheries Laboratory, Lowestoft, Suffolk, \\ NR33 OHT, U.K.
}

(Received 31 May 1989, Accepted 27 June 1989)

Key words: rainbow trout; oxygen debt

The potential for anaerobic metabolism in fish white muscle appears to increase with body size. Larger fish have higher white muscle glycolytic potential (Somero \& Childress, 1980) and display both higher rates of lactate production and higher maximum concentrations of lactate following exhaustive exercise (Goolish, in press). The post-exercise elevation in oxygen consumption by fish ('oxygen debt') is considered to be the result of processes involved in the recovery from anaerobic metabolism (Gaesser \& Brooks, 1984; Milligan \& McDonald, 1988) and therefore may also be influenced by body size. The present study compares the oxygen debt of small and large rainbow trout following exhaustive exercise.

The respirometer consisted of flow-through tubular chambers $(75$ and $4200 \mathrm{ml})$ immersed in a constant water bath $\left(15^{\circ} \mathrm{C}\right)$. Oxygen consumption rates were calculated from the flow rate and the change in dissolved oxygen as measured with a Camlab $\$ 8543$ oxygen meter (Cambridge, U.K.). Mean sizes ( \pm S.E.) of the large and small fish were $32.7 \mathrm{~cm} \pm 3.1$ $(n=4)$ and $7.8 \mathrm{~cm} \pm 0.6(n=3)$, respectively. Individual post-absorptive fish were placed in the respirometer and monitored until stable control levels of oxygen consumption were observed. The fish were then removed, exercised for $6 \mathrm{~min}$, and returned to the respirometer. Maximal burst activity was induced using a net in tanks of approximately the same relative size ( 3 by 4 body lengths). Rates of oxygen consumption were determined after $1,2,3,4,5,6$ and $8 \mathrm{~h}$, and expressed as a percentage of the mean pre-exercise level.

The relative increase in oxygen consumption following exhaustive swimming was higher for the larger fish at each sampling time (Fig. 1). The duration of the response was also longer for the large fish $(8 \mathrm{~h})$ than for the small fish $(5 \mathrm{~h})$. The relative increase in oxygen consumption was significantly higher for the larger fish when the data were combined for the duration of the response $(P<0 \cdot 02)$, but individual sampling times were not significantly different. The higher relative increase for large fish was partly due to their lower standard metabolic rate; 58.6 and $96.1 \mathrm{mg} \mathrm{O}_{2} \mathrm{~kg}^{-1} \mathrm{~h}^{-1}$ for large and small fish, respectively. The area under each curve was used to calculate the total amount of oxygen consumed above pre-exercise levels. Averaged over the duration of the response, the absolute increases in respiration rates following exercise were similar for the large and small fish; 40.4 and $49.5 \mathrm{mg} \mathrm{O} \mathrm{kg}^{-1} \mathrm{~h}^{-1}$, respectively. Post-exercise oxygen consumption expressed per gramme of white muscle was also similar for large $\left(0.69 \mathrm{mg} \mathrm{O}_{2} \mathrm{~g}^{-1}\right)$ and small fish $(0.65 \mathrm{mg}$ $\left.\mathrm{O}_{2} \mathrm{~g}^{-1}\right)$

Having white muscle lactate production (Goolish, in press) and post-exercise oxygen consumption data from the same group of fish also provides an opportunity to examine the relationship between these variables and the cost of glycogen restoration. The oxygen debt data from the group of large fish $(33 \mathrm{~cm})$ are used here because of their lower variability. Lactate production for fish of the length, subtracting the resting level, is $34 \cdot 7 \mu \mathrm{mol} \mathrm{g}^{-1}$ (Goolish, in press). This is equivalent to energy production of $1.94 \mathrm{~J} \mathrm{~g}^{-1}$ of white muscle tissue, assuming a 2:1 ratio between lactate and each glucosyl unit (Stevens \& Black, 1966; Wardle, 1978) and that $558 \mathrm{~J}$ are obtained per gramme of glycogen (Wardle, 1975). The 


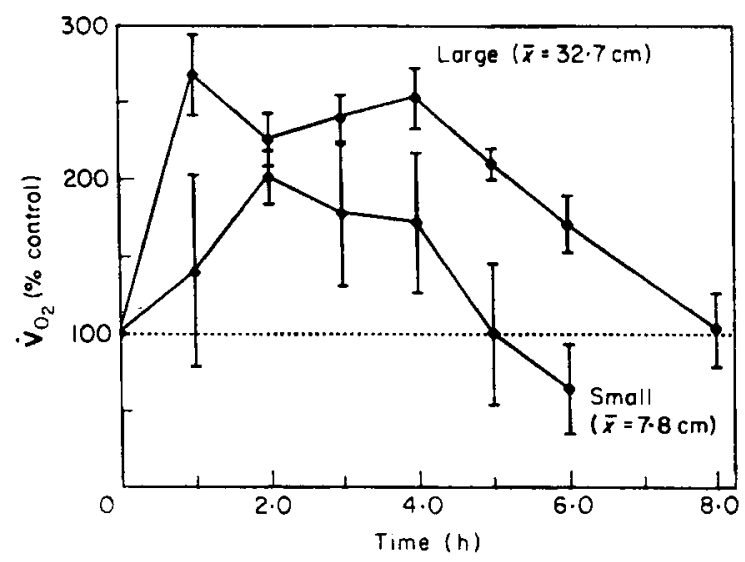

FIG. 1. Rate of oxygen consumption $\left(\dot{\mathrm{V}}_{\mathrm{O} 2}\right)$ by large $(\bar{x}=32.7 \mathrm{~cm})$ and small $(\bar{x}=7.8 \mathrm{~cm})$ rainbow trout after $6 \mathrm{~min}$ of exhaustive exercise. Respiration rates are expressed as a percent of pre-exercise standard metabolic rate $(\bar{x} \pm$ S.E. $)$.

post-exercise elevation in oxygen consumption in these fish is equivalent to $10 \cdot 1 \mathrm{~J} \mathrm{~g}^{-1}$ of white muscle (where $1 \mathrm{mg} \mathrm{O}=14.7 \mathrm{~J}$ ). At 7 ATP per glucosyl unit (Atkinson, 1977), the amount of energy required to replace the glycogen used during the $6 \mathrm{~min}$ of activity would be $6.4 \mathrm{~J} \mathrm{~g} \mathrm{~g}^{-1}$ of white muscle. Of the increase in energy use following exercise, therefore, approximately two-thirds should be accounted for by the resynthesis of the glycogen mobilized during activity. It is not clear what the remaining post-exercise energy use represents, but since the fish were restricted in the respirometry chambers it is not likely to be due to increased activity as has been suggested (Wieser et al., 1985).

This study was supported by a grant from the National Science Foundation (BSR-8700153). I thank the staff of the Fisheries Laboratory, Lowestoft for their cooperation in this study.

\section{References}

Atkinson, D. E. (1977). Cellular Energy Metabolism and its Regulation. New York: Academic Press.

Gaesser, G. A. \& Brooks, G. A. (1984). Metabolic bases of excess post-exercise oxygen consumption: a review. Med. Sci. Sports Exerc. 16, 29-43.

Goolish, E. M. (in press). The scaling of aerobic and anaerobic muscle power in rainbow trout (Salmo gairdneri). J.exp. Biol.

Milligan, C. L. \& McDonald, D. G. (1988). In vivo lacate kinetics at rest and during exhaustive exercise in coho salmon (Oncorhynchus kisutch) and starry flounder (Platichthys stellatus). J. exp. Biol. 135, $119-131$.

Somero, G. N. \& Childress, J. J. (1980). A violation of the metabolism-size scaling paradigm: activities of glycolytic enzymes increase in larger-size fish. Physiol. Zool. 53, 322-337.

Stevens, E. D. \& Black, E. C. (1966). The effect of intermittent exercise on carbohydrate metabolism in rainbow trout, Salmo gairdneri. J. Fish. Res. Bd Can. 23, 47I 485.

Wardle, C. S. (1975). Limits of fish swimming speed. Nature Lond. 255, 725-727.

Wardle, C. S. (1978). Non-release of lactic acid from anaerobic swimming muscle of plaice Pleuronectes platessa L.: a stress reaction. J. exp. Biol. 77, 141-155.

Wieser, W., Platzer, U. \& Hinterleitner, S. (1985). Anaerobic and aerobic energy production of young rainbow trout (Salmo gairdneri) during and after bursts of activity. J. Comp. Physiol. 155, 485-492. 